Print ISSN: 2233-4165 / Online ISSN: 2233-5382

doi:http://dx.doi.org/10.13106/ijidb.2018.vol9.no4.37.

[Review]

\title{
Present and Growth Strategy of the International Journal of Industrial Distribution \& Business
}

\author{
Eung-Kyo Suh*, Dong-Jin Shin**
}

Received: March 14, 2018. Revised: April 1, 2018. Accepted: April 15, 2018.

\section{Abstract}

Purpose - The purpose of this study is to analyze the current status of various fusion research journals and the operational strategies of such journals and compare them with the operational strategies of IJIDB.

Research design, data, and methodology - This study focused on the contents analysis of convergence journals after summarizing the development history from IJIDB's past and its external situation. In addition, we analyzed other strategies such as the number of publication journals, the number of publications, the academic scope, and the impact factor that other convergence journals operate on.

Results - As a result of the analysis, the convergent journals showed to have several related journals, and some journals managed their impact factor well at 5.8. Also, some journals loaded 25 papers in one volume. Also, the managerial functions in IJIDB should be developed further to increase its stability. Finally, opportunities for articles by Candidates of Ph.D. and Masters degree students should be more open to in this field.

Conclusions - If IJIDB finds its competitiveness in comparison with the operational strategies of other convergence journals, it will be the best journal in the Korea Citation Index to receive the most research papers and hospitality from scholars in the Korean journals.

Keywords: International Journal of Industrial Distribution and Business, Korea Distribution of Science Association, Strategy.

JEL Classifications: 120, 123, 129.

\section{Introduction}

With the beckoning of the fourth industrial revolution, all industrial sectors demand a new paradigm, which is reflected in social talents. This has affects across all academic areas, which also include universities. Therefore, the convergence and knowledge sharing in the cross-industry sector is expanding and the academic groups and journals based on convergence are increasing. (Hwang, Lee, Youn, Kim, Lee, Shin, Kim, Kim, Lee, \& Kim, 2016).

Since its publication in 2010, IJIDB has been selected as an index of the Korean Research Foundation's Journal of Citation Index $(\mathrm{KCl})$ in 2017 through its publications ad the

* First Author, Professor, Graduate School of Business, Dankook University, Gyeonggi, Korea.

Tel: +82-31-8005-3981, E-mail: eungkyosuh@dankook.ac.kr

** Corresponding Author, Appenzeller School of Global Business, Paichai University, Korea.

Tel: +82-31-8005-3981, E-mail: jinny774@hotmail.com stable operations of consistent high quality academic papers. In addition, efforts are being made to improve the scope of the thesis and improve as an academic journal. In this situation, the present study aims to establish a strategy for summarizing the present status for IJIDB as well as a comparison of other papers in this area.

\section{A Breakthrough of IJIDB in 2017}

\subsection{Implementation of IJIDB in 2017}

According to the Korea Research Foundation (NRF) statistics, the total number of journals was counted to be 2,378 as of March 2018, including 2,019 types of $\mathrm{KCl}$ indexed registered journals and 359 types of $\mathrm{KCl}$ candidate registered journals (NRF, 2018) (<Table 1>). Of these, 1,425 journals in the humanities and social sciences account for $59.9 \%$ of the total. More precisely, there are more journals 
in the social sciences than any other discipline, and there are 712 entries in the $\mathrm{KCl}$ indexed journal and 142 entries in the $\mathrm{KCl}$ candidate journal. The journals corresponding to $35.9 \%$ of the total journals are registered.

$<$ Table 1> Current Overall status of $\mathrm{KCl}$ indexed journals

\begin{tabular}{|c|c|c|c|}
\hline & $\begin{array}{c}\text { KCl } \\
\text { Indexed }\end{array}$ & $\begin{array}{c}\text { KCl } \\
\text { Indexed } \\
\text { Candidate }\end{array}$ & Total \\
\hline Humanity & 513 & 58 & 571 \\
\hline Social Science & 712 & 142 & 854 \\
\hline Science & 112 & 16 & 128 \\
\hline Engineering & 208 & 32 & 240 \\
\hline Medicine \& Pharmaceuticals & 221 & 60 & 281 \\
\hline Agriculture, Fishery, \& Marine & 69 & 6 & 75 \\
\hline Arts and sports & 107 & 21 & 128 \\
\hline Interdisciplinary Science & 77 & 24 & 101 \\
\hline Total & 2,019 & 359 & 2,378 \\
\hline
\end{tabular}

Source: $\mathrm{KCl}$ Homepage

In the social sciences where a majority of journals exist, the IJIDB Impact Factor is 1.41, which is the second highest among 54 journals in the field of economics. This was the result of the continuous management of the citation rate at the institute level, the recruitment of excellent papers, and the dedication of the directors and members of the institute. In direct correlation with this, the journal was selected as the index of the $\mathrm{KCl}$ index of the Korea Research Foundation in 2017.

The executives of the Korea Distribution Science Society decided to make 2017 the first year of the second development of the mountain study journal, and greatly improved the articles of association, scope and executives of the journal. First, we changed from publishing English papers to incorporating a mixture of English and Korean articles. We revised the journal to publish four times a quarter, once a quarter, once a month for 12 times a year. In addition, the scope of the dissertation limited to the field of distribution science has been further expanded to include industrial economics, industrial management, and other convergence fields, and is characterized by application economics, health care, agroeconomics, behavioral consumer economics, information systems, Travel, and hotel management. This was in accordance with laying the foundations for dealing with the complex and diverse academic needs of the 4th Industrial Revolution era.

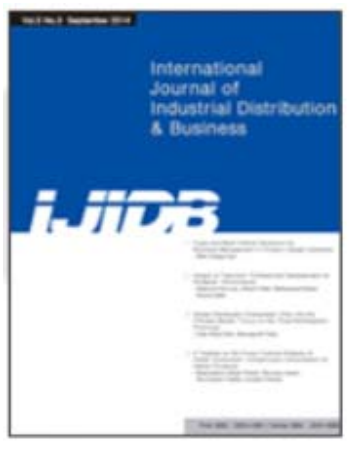

Source: IJIDB Journal Homepage

\section{International Journal of Industrial Distribution \& Business 산경연구논집(産經研究論集)}

Frequency : Monthly (Twelve issues per year)

Languages : English or Korean

ISSN : 2233-4165 (Print)

ISSN : 2233-5382 (Online)

Year of Launching : 2010

Publisher: KODISA

Indexed/Tracked/Covered By : Korea Citation Index, Global Impact Factor, and Crossref.

<Figure 1> IJIDB Journal Covers, 2018

$<$ Table 2> Brief History of IJIDB Journal

\begin{tabular}{|c|c|c|}
\hline Date & Major Activities & Remarks \\
\hline Dec. 2010. & IJIDB Vol. 1(1) Published & \\
\hline June. 2014. & IJIDB scheduled to be submitted for an evaluation in 2014 & \\
\hline Aug. 2014 & IJIDB online system introduction to incorporate ACOMS and doi & \\
\hline Oct. 2014 & IJIDB Global platform renewal work & \\
\hline Jan. 2015 & IJIDB listed as a KCl index Candidate & \\
\hline Apr. 2017 & IJIDB listed in the KCl index & kodisa.jams.or.kr \\
\hline June. 2017 & IJIDB moved to JAMS Platform & \\
\hline
\end{tabular}


$<$ Table 3> Current status of IJIDB

\begin{tabular}{|c|c|l|}
\hline & \multicolumn{1}{|c|}{ Before } & \multicolumn{1}{c|}{ After } \\
\hline Status & $\mathrm{KCl}$ index candidate & $\mathrm{KCl}$ Indexed \\
\hline $\begin{array}{c}\text { Publication } \\
\text { Frequency }\end{array}$ & Quarterly & $\begin{array}{l}\text { Monthly (12 issues per year) } \\
(7 \text { issues published in 2017: May, June, August, September, October, November, December) }\end{array}$ \\
\hline Languages & English & English, Korean Bilingual \\
\hline & $\begin{array}{l}\text { Industrial Distribution } \\
\text { Finance Economy, Technology Economy, Real estate Economy, Applied Economics, Healthcare } \\
\text { Economy, Consumer Economy, Agricultural Economics, Environment Economy, Distribution } \\
\end{array}$ & $\begin{array}{l}\text { Economics, Other Related Areas } \\
\text { Industrial Management } \\
\text { Sanagement Strategy, Management Information System, Human Resource Management, } \\
\text { Marketing, Logistics, Medical/Health Management, Clothing Management, Sports Management, } \\
\text { Welfare Management, International Tourism \& Hospitality, Other Related Areas }\end{array}$ \\
\hline
\end{tabular}

\subsection{Summary of IJIDB Journals}

The IJIDB Journal has published fifteen papers in 2016, but has made remarkable progress since the publication of 42 papers from 2017. Along with this, diversity has been developed in the academic field. It was published in twelve academic fields in 2016, and it was published in twenty-four academic fields in 2017, which shows that the academic field has been expanded and doubled. As shown in <Table $4>$, if the frequency of thesis on topics such as Economics, Management information, and social issues was high in 2016, then in 2017, Economics, Medical Economics, Management Information Systems, Medical \& Health Management, Distribution Economics, Strategy IJIDB's journals are used in a wide variety of academic fields such as business, management, marketing, information management, and business management.

<Table 4> Major Publication Fields of IJIDB

\begin{tabular}{|c|c|c|}
\hline & $\mathbf{2 0 1 6}$ & $\mathbf{2 0 1 7}$ \\
\hline Economics & 3 & 4 \\
\hline Real Estate Economy & & \\
\hline Distribution Economics & & 2 \\
\hline Sports Management & 1 & 2 \\
\hline Strategy & & 3 \\
\hline Medical Economics & & \\
\hline Welfare Management & & \\
\hline Logistics \& SCM & 1 & 1 \\
\hline Distribution Strategy \& Competitiveness & 1 & 1 \\
\hline Distribution Information Technology (DIT) & & 1 \\
\hline Human Resource Management & & \\
\hline Clothing Management & 1 & \\
\hline Material \& Acquisition Management & & \\
\hline Marketing & & 2 \\
\hline Management Strategy & & \\
\hline Distribution Channel Management & & 1 \\
\hline Consumer Economy & & 2 \\
\hline
\end{tabular}

\begin{tabular}{|c|c|c|}
\hline & 2016 & $\mathbf{2 0 1 7}$ \\
\hline Agricultural Economics & & 1 \\
\hline Traditional Market Development \& Management & & 2 \\
\hline Management Information System & 2 & 3 \\
\hline Environment Economy & & \\
\hline Medical / Health Management & & 3 \\
\hline Finance Economy & & 2 \\
\hline Finance & & \\
\hline Distribution Science \& Innovation & 1 & 2 \\
\hline Consumer Behavior \& CRM & 1 & 1 \\
\hline Business & & \\
\hline Innovative system \& Industry & & \\
\hline Marketing and Information Management & & 2 \\
\hline Business Management & 1 & 2 \\
\hline Electric Commerce & & 1 \\
\hline Trade Business & & 1 \\
\hline Applied Economics & & \\
\hline Logistics & & 1 \\
\hline Technology Economy & & \\
\hline Social Issues & 2 & \\
\hline Manufacturing/Wholesaling/Retailing & 1 & \\
\hline Management & & 1 \\
\hline Management & 1 & 1 \\
\hline Miscellaneous & 42 \\
\hline Total & & \\
\hline
\end{tabular}

\subsection{Journal Submissions and Rejection Status}

A total of 31 papers were submitted and fifteen of them were published in IJIDB (<Table 5>). Overall, the approval rate is $50 \%$, which is lower from $56.2 \%$ in 2015 to $50.8 \%$ in 2016. This is the result of IJIDB's editorial team's efforts to improve the quality of the paper. By month, we were able to see the approval rate of $80 \%$ in the December 2015 issue, and the approval rate in October of 2016 was $36.4 \%$.

The IJIDB editorial team seems to have stabilized the approval / approval rate for each issue through their hard work and dedication to the quality of the publications. 
$<$ Table 5> Submissions and Rejection Rate of IJIDB

\begin{tabular}{|c|c|c|c|c|c|c|}
\hline Year & Date of Publication & Volume, Issue & $\begin{array}{l}\text { Number of } \\
\text { Submissions } \\
\text { (A) }\end{array}$ & $\begin{array}{c}\text { Number of } \\
\text { Published Papers } \\
\text { (B) }\end{array}$ & $\begin{array}{c}\text { Number of } \\
\text { Rejected Papers }\end{array}$ & $\begin{array}{l}\text { Published Rate } \\
\qquad\left(B / A^{*} 100\right)\end{array}$ \\
\hline \multirow{5}{*}{2015} & March 30 & Vol. 6(1) & 6 & 4 & 2 & $66.7 \%$ \\
\hline & June 30 & Vol. 6(2) & 7 & 4 & 3 & $57.1 \%$ \\
\hline & September 30 & Vol. 6(3) & 7 & 4 & 3 & $57.1 \%$ \\
\hline & December 30 & Vol. 6(4) & 5 & 4 & 1 & $80.0 \%$ \\
\hline & Total & & 25 & 16 & 9 & $56.2 \%$ \\
\hline \multirow{5}{*}{2016} & March 30 & Vol. 7(1) & 7 & 4 & 3 & $57.1 \%$ \\
\hline & June 30 & Vol. 7(2) & 7 & 3 & 4 & $42.9 \%$ \\
\hline & September 30 & Vol. 7(3) & 6 & 4 & 2 & $66.7 \%$ \\
\hline & December 30 & Vol. 7(4) & 11 & 4 & 7 & $36.4 \%$ \\
\hline & Total & & 31 & 15 & 16 & $50.8 \%$ \\
\hline
\end{tabular}

\section{Present Strategy of Other Convergence Related Journals}

Recently, according to the academic demand for fusion science in the era of the 4th Industrial Revolution, there has been an increasing number of cases of publishing journals in one academic society by presenting many academic disciplines as a fusion society (Hwang, Kim, Youn, Lee, \& Lee, 2014; Hwang, Lee, Lee, Kim, Yang, Youn, \& Kim, 2015; Hwang \& Youn, 2016). Particularly, the relevant institutes have shown the tendency of enlargement by increasing the number of journals published and organizing through the management of specialized institute operators. Therefore, one existing academic society deals with one specialty area and moves away from the format of one journal (Kim \& Youn, 2012; Kim, Kim, \& Youn, 2010), which deals with various academic areas.

Among various cases related to this, the Humanities and Social Sciences Technology Convergence Society in <Figure $2>$ has the purpose of studying humanities research and industrial technology convergence of IT, BT, and NT industries, Development, dissemination and technology development strategy. The details are given in <Table 6>.

Most of the journals do not limit the scope of the academic field, but they treat and publish the thesis in all disciplines. The IJIDB (International Journal of Industrial Distribution \& Business) of Korea Distribution Science Society is also very encouraging part of the academic field since 2017, but its academic scope is still limited compared to other journals. In the future, it will be necessary to take a serious look at the academic field of the Journal of the Mountain Ridge Journal, and it is necessary to start from the field of convergence with the adjacent academic field in the short term, for example, Method.

In particular, most of these fusion-related journals have great features in management, and they have a very wide range of academic field and the number of judges. Most convergent scholarly journals are invited by jury members of various majors and have established their own domain to suit their academic fields.
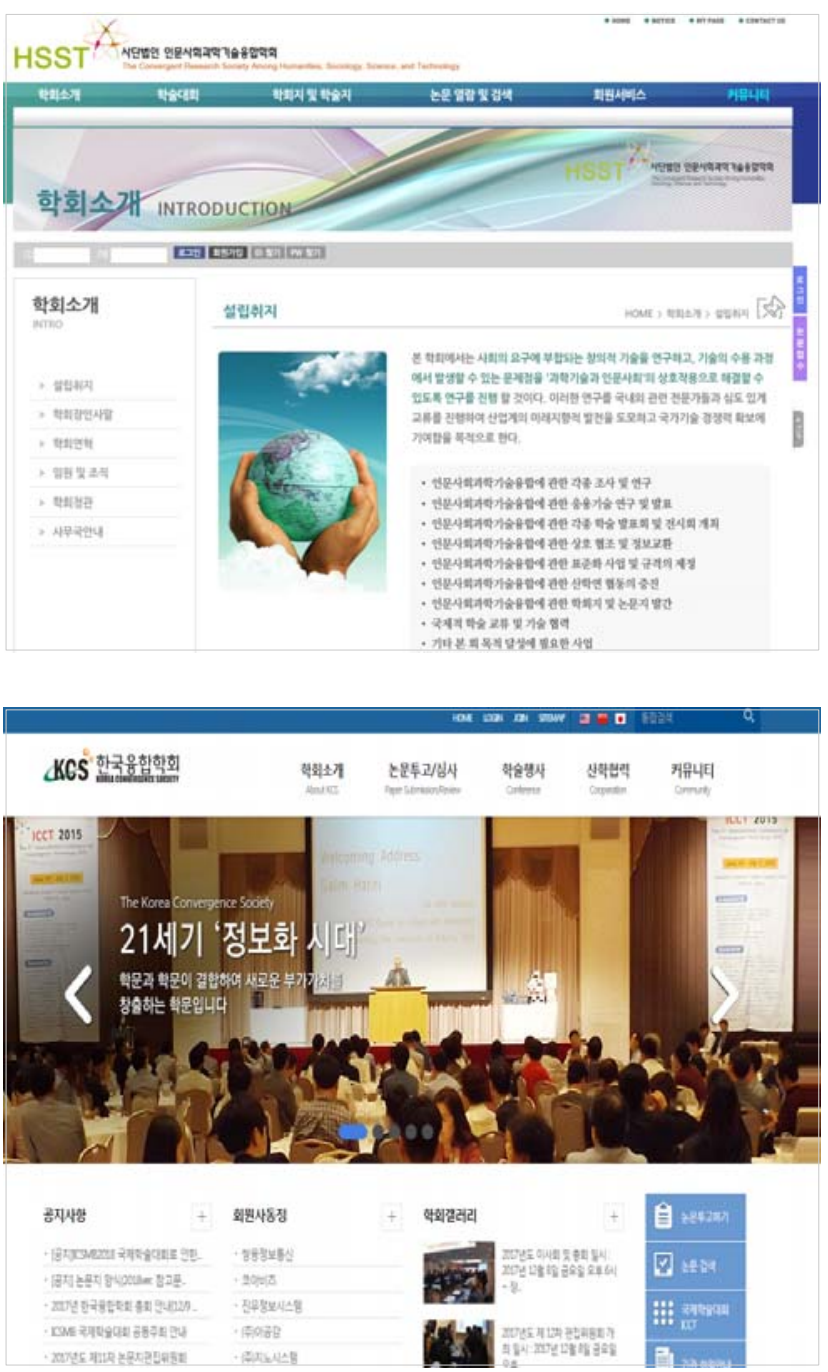

Source: Homepage of each association

<Figure 2> Examples of Convergence Research Society 
$<$ Table 6> Characteristics of Convergence related Society

\begin{tabular}{|c|c|c|}
\hline & $\begin{array}{l}\text { The Convergent Research Society Among Humanities, } \\
\text { Sociology, Science and Technology }\end{array}$ & Korea Convergence Society \\
\hline Web site & - http://hsst.or.kr & - http://www.kcons.or.kr \\
\hline Scope & $\begin{array}{ll}\text { - } & \text { IT(Information Technology) } \\
\text { - } & \text { BT(Bio-Medical Technology) } \\
\text { - } & \text { NT(Nano Technology) } \\
\text { - } & \text { Convergence }\end{array}$ & $\begin{array}{ll}\text { - } & \text { IT(Information Technology) } \\
\text { - } & \text { BT(Bio-Medical Technology) } \\
\text { - } & \text { Business } \\
\text { - } & \text { MT(Culture Technology) } \\
\text { - } & \text { ST(Social Technology) } \\
\text { - } & \text { WT(Wellness Technology) } \\
\text { - } & \text { NT(Nursing Technology) } \\
\text { - Convergence }\end{array}$ \\
\hline Journals & $\begin{array}{l}\text { - Asia-pacific Journal of Multimedia Services Convergent } \\
\text { with Art, Humanities, and Sociology } \mathrm{KCl} \text { Index } \\
\text { - Asia-pacific Journal of Convergence Research } \\
\text { Interchange ( } \mathrm{KCl} \text { Candidate) } \\
\text { - Journal of Security Engineering(KCl Index Candidate) }\end{array}$ & $\begin{array}{l}\text { - Journal of the Korea Convergence Society } \\
(\mathrm{KCl} \text { Index : Impact Factor - 5.85) }\end{array}$ \\
\hline Feature & - 12 issues per year & $\begin{array}{l}\text { - Over } 25 \text { papers per issues } \\
\text { - } 6 \text { issues per year }\end{array}$ \\
\hline
\end{tabular}

The Journal of Humanities and Social Sciences, Technology and Convergence has three sister journals and publishes twelve journals a year. The Korea Convergence Institute has one journal of the Korea Convergence Institute and publishes 6 issues a year. However, through thorough management, the Influence Index is maintained in the latter half of the five points.

\section{Future Strategy for IJIDB Journals}

Currently, the mountain climbing research book needs stabilization in 2017. Also, the contribution rate of the journal is not stable. In addition, new journals in the field of fusion research are intensifying the external competition environment. Therefore, it is necessary to pursue the development plan as follows.

First, the number of English papers and Korean papers should be expanded in order to foster mountain peering research papers together with KODISA as global $\mathrm{SCl}$ level entry points. It is not easy to manage the coverage rate due to the low contribution rate of the current thesis. It is difficult to get a good evaluation on the inspections of the inspections, so it is necessary to promote through various domestic and foreign channels.

Second, qualitative growth of a mountain study book is necessary. It is necessary to make efforts to keep the authors' adherence to the submission procedure and research ethics thoroughly. It is necessary to support the publication of improved papers by revising or revising more than the second one. In order to do this, we must support the revision service (Korean editing) provided by the society and native language correction.

Third, active participation of overseas scholars is necessary for regional scholarly distribution. It is necessary to support more international scholars to register as a member of KODISA and the Mountain Ridge Researching Society by carrying out active publicity of international academic conferences held twice a year.

Fourth, diversification of the academic field is needed. It is a reality that the scholarly research papers which denote the fusion related journals are still limited in the academic field as compared with the other fusion journals. This is due to factors such as the difficulty of operating the academic journals and the difficulty of accepting judges. However, if we include academic fields such as business education, distribution education, entrepreneurship education, online corporate education through convergence with the field of education from the fields of economics and business administration, for example, and gradually spreading the convergence field, this will aid in solidifying the status as a top academic journal.

Next, in order to expand investment in academic journals, it is necessary to strengthen the independence of academic journals and to actively support corporations through industry-academia cooperation on nonprofit academic societies. In particular, it is necessary to actively attract members who are working in the industry to consider sponsoring company-level academic societies. In particular, in the case of large-scale academic events, it should be possible to organize academic and outwardly balanced events through the creation of external funds.

Finally, various efforts are needed for the distribution of scholars in each region. First, domestic academic 
organizations are divided into metropolitan areas and non-metropolitan areas, and are often operated according to regional characteristics. The structure of these regional academic institutions will only add to the obstacles and will not help to advance to world-class academic institutions through internationalization. Therefore, it is necessary to promote the participation of many scholars in universities by attracting members from various universities in the country and by actively collaborating with universities abroad.

IJIDB is in the year of its first year growth in 2018. A lot of effort is needed to consolidate its position as the best professional academic journal in Korea and to be a leading global academic journal in the future.

\section{References}

Hwang, H. J., Lee, J. H., Lee, J. W., Kim, Y. E., Yang, H. C., Youn, M. K., \& Kim, D. H. (2015). Strengthening Publication Ethics for KODISA Journals: Learning from the Cases of Plagiarism. Journal of Distribution Science, 13(4), 5-8.

Hwang, H. J., Lee, J. W., Youn, M. K., Kim, D. H., Lee, J. H., Shin, D. J., Kim, B. G., Kim, T. J., Lee, Y. K., \& Kim, W. K. (2017). Future Development Strategies for KODISA Journals: Overview of 2016 and Strategic Plans for the Future. Journal of Distribution Science, 15(5), 75-83.

Hwang, H. J., Kim, D. H., Youn, M. K., Lee, J. W., \& Lee, J. H. (2014). The Standard of Judgement on Plagiarism in Research Ethics and the Guideline of Global Journals for KODISA. Journal of Distribution Science, 12(6), 15-20.

Hwang, H. J., \& Youn, M. K. (2016). Based on Proven Practices in Violation of Research Ethics for the KODISA Journals. The International Journal of Industrial Distribution \& Business, 71), 5-10.

Kim, D. H., \& Youn, M. K. (2012). Present and Future of the Journal of Distribution Science. Journal of Distribution Science, 105), 7-17.

Kim, Y. M., Kim, Y. E., \& Youn, M. K. (2010). Analysis of Research Trends in Journal of Distribution Science. Journal of Distribution Science, 8(4), 7-17.

NRF (2017). Korea Citation Index, Statistics Information. Retrieved February 20, 2018 from https://www.kci.go.kr /kciportal/po/statistics/poStatisticsMain.kci.

Youn, M. K., Lee, J. H., Kim, Y. E., Yang, H. C., Hwang, H. J., Kim, D. H., \& Lee, J. W. (2015). KODISA Journals and Strategies. Journal of Distribution Science, 13(3), 5-9. 